\title{
Analisis Status Mutu Air Sungai Berdasarkan Metode STORET Sebagai Pengendalian Kualitas Lingkungan (Studi Kasus: Dua Aliran Sungai di Kecamatan Tembilahan Hulu, Kabupaten Indragiri Hilir, Riau)
}

\author{
Masykur HZ ${ }^{1 *}$, Bintal Amin ${ }^{2}$, Jasril ${ }^{3}$, Sofyan Husein Siregar ${ }^{2}$ \\ ${ }^{1}$ Badan Perencanaan Pembangunan Daerah Kabupaten Indragiri Hilir Jl Akasia No.02 Tembilahan Riau \\ ${ }^{2}$ Fakultas Perikanan dan Kelautan Universitas Riau Jalan Binawidya KM 12,5 Simpang Panam \\ ${ }^{3}$ Fakultas FMIPA Universitas Riau Kampus Bina widya Panam KM 12.5 Pekanbaru.
}

\begin{abstract}
District of Tembilahan Hulu is the capital of Indragiri Hilir Regency which has two rivers, namely the Sungai Parit 11 and Sungai Parit 13. These rivers has a tidal type with the estuary on the Indragiri River. The function of these rivers is used as a rain water drainage that existence is not be separated from human activities around the watershed. Characteristics of rivers that cross urban areas are susceptible to decreasing water quality and environmental pollution from the effects of high anthropogenic activities. This study aims to analyze the status of water quality in two rivers that cross district of Tembilahan Hulu, Indragiri Regency. Sungai Parit 11 as the research area has a length of $\pm 5 \mathrm{~km}$ and Sungai Parit 13 has a length of $\pm 6 \mathrm{~km}$, each of which is divided into 3 locations of sampling points representing the condition of tides and low tides. The placement of each sampling point is determined based on the representation of the upstream, middle and downstream of the river. Analysis of water quality status of the rivers is made using STORET method which comprehensive by Decree of the Minister of Environment of the Republic of Indonesia Number 115 Year 2003. The results showed the status of water quality of Sungai Parit 11 and Sungai Parit 13 in District of Tembilahan Hulu, Indragiri Hilir regency in heavily polluted conditions.
\end{abstract}

Key words: Anthropogenic activities, river quality status, STORET Index.

Kerusakan sumber daya perairan yang terjadi pada saat ini adalah terjadinya pencemaran sungai. Sungai merupakan badan air yang bersifat terbuka dan mudah menerima limbah berbagai aktivitas manusia dari daerah permukiman, pertanian dan industri di sekitar daerah aliran sungai (DAS). Masukan pencemar secara langsung ke sungai akan menimbulkan penurunan kualitas air berupa terjadinya perubahan parameter fisika, kimia dan biologi perairan sungai.

Salah satu indikator terjadinya degradasi terhadap air sungai dapat dilihat dari adanya perubahan parameter kualitas air. Perubahan tersebut dapat disebabkan oleh adanya aktivitas pembuangan limbah, baik limbah pabrik/industri, pertanian, maupun limbah dosmetik dari suatu pemukiman penduduk ke dalam badan air suatu perairan. Perairan merupakan satu kesatuan (perpaduan) antara komponen-komponen fisika, kimia, dan biologi dalam suatu media air pada wilayah tertentu. Ketiga komponen tersebut saling berinteraksi, jika terjadi perubahan pada salah satu komponen maka akan berpengaruh terhadap komponen yang lainnya (Rudiyanti, 2011).

Sungai yang mengalir di Kecamatan Tembilahan Hulu terdiri dari Sungai Parit 11 dan Sungai Parit 13 dengan bermacam aktifitas antropogenik di sepanjang bantaran sungai dari hulu hingga ke hilirnya. Sebagaimana sungaisungai yang mengaliri kawasan perkotaan, kedua sungai ini juga mengalami tekanan dari bermacam aktivitas antropogenik perkotaan. Secara geografis, kedua sungai ini terletak pada koordinat $0^{\circ} 19^{\prime} 4.20^{\prime \prime} \mathrm{LS}-0^{\circ} 19^{\prime} 33.55^{\prime \prime} \mathrm{LS}$ dan $103^{\circ} 8^{\prime} 15.18^{\prime \prime}$ BT - 103 ${ }^{\circ} 9^{\prime} 44.67^{\prime \prime}$ BT dengan arah aliran bermuara ke Sungai Indragiri. Sungaisungai ini bertipe pasang surut, kondisi lingkungan sangat fluktuatif karena dipengaruhi oleh kondisi pasang dan surut yang terjadi di Sungai Indragiri.

Pertumbuhan penduduk dan perkembangan Kota Tembilahan yang demikian pesat telah memicu terjadinya alih fungsi bantaran sungai menjadi areal permukiman, 
pasar, perbengkelan, perhotelan dan rumah sakit. Dampak dari bermacam-macam aktivitas tersebut adalah terjadinya pencemaran sungai akibat limbah yang dibuang secara langsung ke sungai sehingga menyebabkan menurunnya kualitas air sungai baik secara fisika, kimia maupun biologi. Kasry (2005) menyatakan bahwa limbah yang dibuang langsung ke sungai cepat atau lambat akan menyebabkan terlampauinya kemampuan sungai untuk membersihkan diri sendiri (self purification), sehingga akan menimbulkan permasalahan yang serius yaitu pencemaran perairan. Perairan yang tercemar akan berpengaruh negatif terhadap kehidupan biota perairan dan kesehatan masyarakat yang memanfaatkan air sungai tersebut.

Badan Lingkungan Hidup Provinsi tahun 2015 merilis beberapa data parameter kualitas fisika dan kimia air Sungai Indragiri yang diketahui telah melampaui baku mutu air kelas IV berdasarkan PP No. 82 Tahun 2001. Parameter-parameter tersebut antara lain TDS, TSS, BOD, $\mathrm{NO}_{3}, \mathrm{NH}_{3}$, Fecal dan total Coliform (BLH Provinsi Riau, 2015). Kondisi ini mengindikasikan bahwa telah terjadi penurunan kualitas air yang ditandai dengan terjadinya penurunan status mutu air dari kondisi normal. Aktivitas industri, limbah perkotaan di sepanjang perairan sungai akan memberikan dampak buruk terhadap perairan tersebut yang ditandai dengan masuknya sejumlah beban pencemar ke dalam lingkungan perairan yang menyebabkan terganggunya ekosistem dan degradasi lingkungan (Delgado dalam Agustina, et al., 2012).

Status mutu air adalah tingkat kondisi mutu air yang menunjukan kondisi cemar atau kondisi baik pada suatu sumber air dalam waktu tertentu dengan membandingkan dengan baku mutu air yang ditetapkan. Penentuan status mutu air dapat dilakukan salah satunya dengan menggunakan Metode STORET. Metode STORET merupakan metode yang digunakan untuk mengetahui parameter yang memenuhi atau melampaui Baku Mutu Air dengan cara membandingkan antara data kualitas air dengan baku mutu air yang disesuaikan dengan kelas dan peruntukannya merujuk pada Peraturan Pemerintah Nomor 82 Tahun 2001 tentang pengelolaan kualitas air dan pengendalian pencemaran air (KLH, 2003).
Berdasarkan latar belakang di atas, maka tujuan penelitian dalam penelitian ini mengkaji kondisi kualitas air dan status mutu air di kedua Sungai yang mengaliri Kecamatan Tembilahan Hulu Kabupaten Indragiri Hilir serta kesesuaiannya terhadap baku mutu air sesuai peruntukannya

\section{BAHAN DAN METODE}

Penelitian ini merupakan penelitian deskriptif kuantitatif. Penelitian dilaksanakan pada bulan Mei hingga Juni 2017, bertempat di Kabupaten Indragiri Hilir tepatnya di Sungai Parit 11 dan Sungai Parit 13 yang berada di Kecamatan Tembilahan Hulu. Alat-alat yang digunakan dalam penelitian ini yaitu: 1) GPS Garmin CSx, untuk menentukan titik koordinat lokasi pengambilan sampel (lintang, bujur dan elevasi) pada peta; 2) thermometer sebagai alat untuk mengukur suhu perairan; 3) horiba water quality sebagai alat untuk mengukur $\mathrm{pH}$ dan oksigen terlarut; 4) secchi disk sebagai alat untuk mengukur kecerahan perairan; 5) current drogue sebagai alat untuk mengukur kecepatan arus; 6) hand Refaktometer Atago sebagai alat untuk mengukur salinitas; 7) botol sampel 500 dan $1000 \mathrm{ml}$ sebagai tempat sampel air; 8) Ice box sebagai tempat pengawetan sampel air; dan 9) kertas label dan alat tulis yang digunakan untuk mencatat hasil pengamatan.

Penentuan titik pengambilan sampel air menggunakan metode purposif sampling, yaitu cara penentuan titik pengambilan sampel air dengan melihat pertimbangan-pertimbangan yang dilakukan oleh peneliti antara lain didasari atas kemudahan askes, biaya maupun waktu dalam penelitian. Berikut ini merupakan 6 (enam) titik lokasi pengambilan sampel air sungai di Sungai Parit 11 dan Sungai Parit 13 yang dibagi menjadi stasiun-stasiun dalam penelitian ini sebagaimana yang disajikan pada Tabel 1. 
Tabel 1. Koordinat Stasiun Pengamatan Penelitian

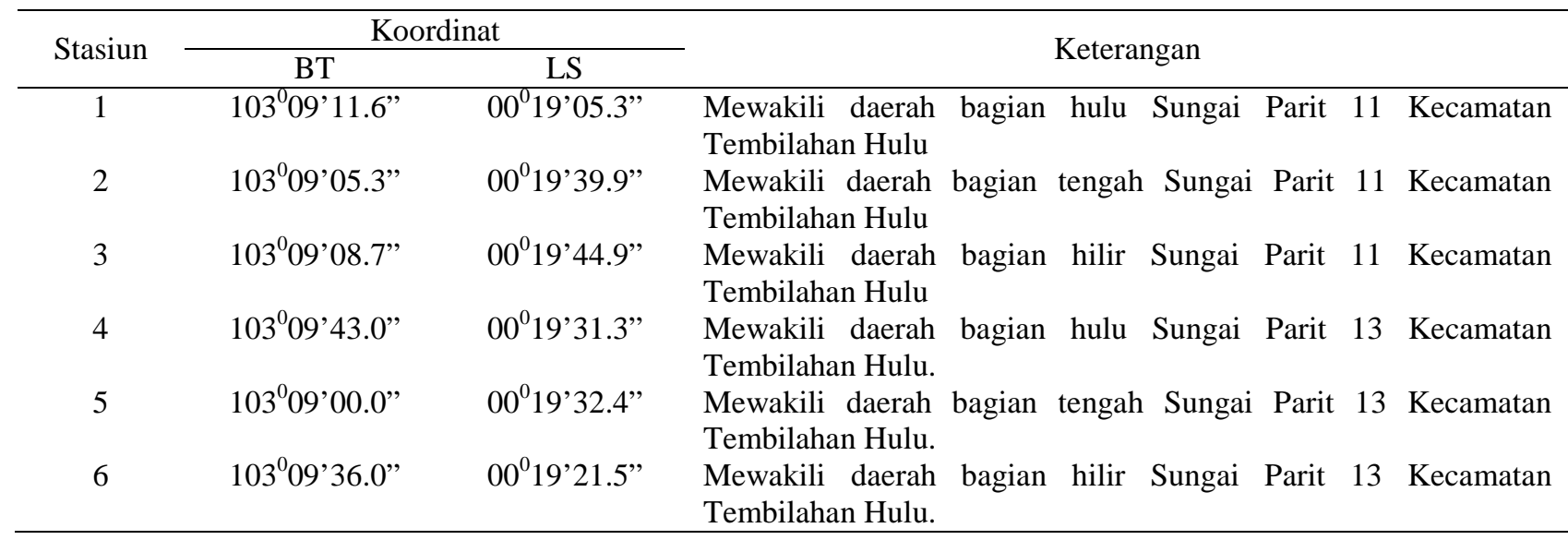

Pengambilan sampel pada air sungai diambil dengan cara pengambilan sampel sesaat (grab sample) yang mewakili kondisi pasang dan surut. Sampel sesaat atau grab sample yaitu sampel yang diambil secara langsung dari badan air yang sedang dipantau, sampel ini hanya menggambarkan karakteristik air pada saat pengambilan sampel (Effendi, 2003). Setelah proses pengambilan sampel air pada setiap stasiun pengambilan yang telah ditentukan, untuk sampel yang dilakukan pengujian di laboratorium, maka perlu adanya penanganan sampel sesuai standar yang ditetapkan.
Penanganan sampel air berupa pengamanan sampel dilapangan (pemberian label pada setiap wadah sampel), pengawetan sampel (pendinginan dan penambahan bahan kimia) dan transportasi sampel (dari lokasi pengambilan sampel ke laboratorium). Pengawetan sampel dimaksudkan agar tidak terjadi perubahan secara fisika dan kimia. Sebaran stasiun pengambilan sampel air dapat dilihat pada Gambar 1.

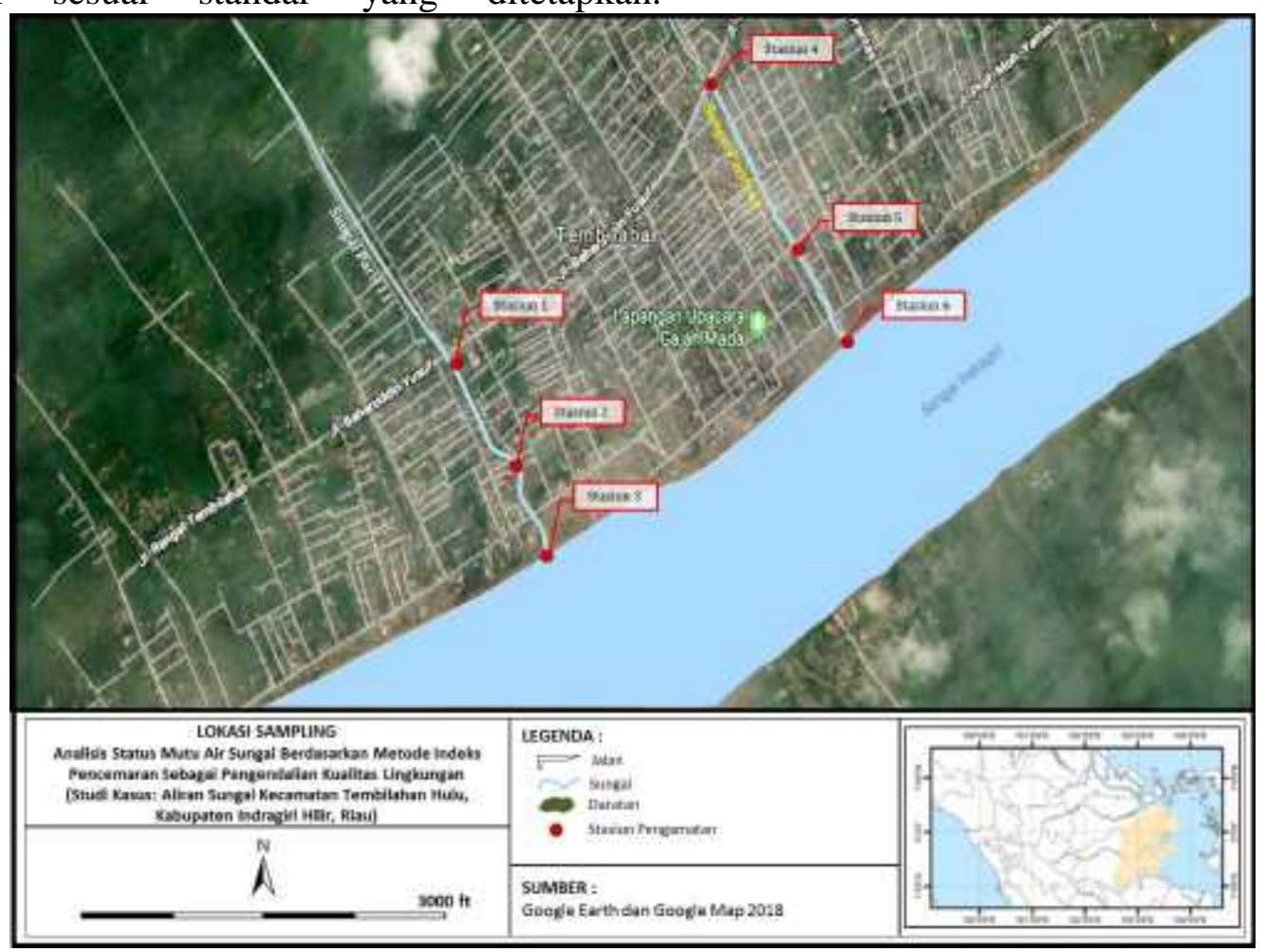

Gambar 1. Lokasi Stasiun Pengamatan Penelitian dan Pengambilan Sampel Air Sungai 
Pengujian kualitas air sungai dalam penelitian ini untuk parameter $\mathrm{pH}$ dan suhu pengujian dilakukan langsung di lapangan dengan menggunakan alat ukur $\mathrm{pH}$ dan suhu air. Sedangkan untuk parameter TSS, DO, COD, BOD, Phosfat dan Nitrat dilakukan pengujian di Laboratorium Ekologi Perairan, Jurusan Menajemen Sumberdaya Perairan, Fakultas Perikanan dan Ilmu Kelautan Universitas Riau. Pengujian kualitas air dilakukan dengan menggunakan metode sesuai ketentuan standar yang berlaku. Metode pengujian kualitas air dapat dilihat pada Tabel 2. Data yang telah didapat dari hasil pengujian parameter fisik dan kimia air Sungai, baik itu di lapangan maupun di laboratorium, kemudian dilakukan analisa kualitas air Sungai Parit 11 dan Sungai Parit 13 dengan membandingkan hasil pengujian dengan baku mutu air kelas III berdasarkan Peraturan Pemerintah Nomor 82 Tahun 2001 tentang Pengelolaan Kualitas Air dan Pengendalian Pencemaran Air.

Tabel 2. Metode Pengujian Kualitas Air

\begin{tabular}{lcll}
\hline \multicolumn{1}{c}{ Parameter } & Satuan & \multicolumn{1}{c}{ Metode } \\
\hline Fisika & & & Keterangan \\
Suhu & ${ }^{0} \mathrm{C}$ & SNI 06-6989.23-2005 & Pengujian In situ \\
TSS & $\mathrm{mg} / \mathrm{l}$ & APHA. 2540 D-2005 (Gravimetri) & Pengujian di Laboratorium \\
Kimia & & & \\
pH & - & SNI 06-6989.11-20041 & Pengujian In situ \\
DO & $\mathrm{mg} / \mathrm{l}$ & QI/LKA/02 (Elektrometri) & Pengujian In situ \\
BOD & $\mathrm{mg} / 1$ & APHA. 5210 B-1998 & Pengujian di Laboratorium \\
COD & $\mathrm{mg} / 1$ & QI/LKA/19 (Spektrofotometri) & Pengujian di Laboratorium \\
Nitrat $\left(\mathrm{NO}_{3}\right)$ & $\mathrm{mg} / 1$ & QI/LKA/65 & Pengujian di Laboratorium \\
Phosfat $\left(\mathrm{PO}_{4}\right)$ & $\mathrm{mg} / \mathrm{l}$ & SNI 19-2483-199 & Pengujian di Laboratorium \\
\hline
\end{tabular}

Sumber: Laboratorium Ekologi Perairan dan Laboratorium Ilmu Kelautan Faperika UR (2017).

Penentuan status mutu air sungai dalam penelitian ini dilakukan dengan menggunakan metode Indeks STORET mengacu pada Keputusan Menteri Negara Lingkungan Hidup Nomor 115 Tahun 2003 tentang Pedoman Penentuan Status Mutu Air. Metode STORET merupakan metode yang digunakan untuk mengetahui parameter yang memenuhi atau melampaui Baku Mutu Air. Secara prinsip Metode STORET adalah membandingkan antara data kualitas air dengan baku mutu air yang disesuaikan dengan kelas dan peruntukannya merujuk pada Peraturan Pemerintah Nomor 82 Tahun 2001 tentang pengelolaan kualitas air dan pengendalian pencemaran air. Pada penelitian ini klasifikasi kelas mutu air yang digunakan adalah kelas III, yaitu air yang dapat digunakan untuk pembudidayaan ikan air tawar, peternakan, air untuk mengairi tanaman dan atau peruntukan lain yang mensyaratkan mutu air yang sama dengan kegunaan tersebut (KLH, 2001).

Penentuan Status Mutu Air dengan menggunakan Metode STORET dilakukan dengan langkah-langkah sebagai berikut: (a) Melakukan pengumpulan data kualitas air dan debit air secara periodik; (b) Membandingkan data hasil pengukuran dari masing-masing parameter air dengan nilai baku mutu yang sesuai dengan kelas air; (c) Jika hasil pengukuran memenuhi nilai baku mutu air (hasil pengukuran < baku mutu) maka diberi skor 0; (d) Jika hasil pengukuran tidak memenuhi nilai baku mutu air atau (hasil pengukuran > baku mutu ) maka diberi skor sesuai dengan Tabel 3; (e) Jumlah negatif dari seluruh parameter dihitung dan ditentukan status mutunya dari jumlah skor yang didapat dengan menggunakan sistem nilai Tabel 4. 
Tabel 3. Penentuan Sistem Nilai untuk Menentukan Status Mutu Air dengan Metode STORET

\begin{tabular}{|c|c|c|c|c|}
\hline \multirow{2}{*}{$\begin{array}{l}\text { Jumlah } \\
\text { Contoh }\end{array}$} & \multirow{2}{*}{ Nilai } & \multicolumn{3}{|c|}{ Parameter } \\
\hline & & Fisika & Kimia & Biologi \\
\hline \multirow{3}{*}{$<10$} & Maksimum & -1 & -2 & -3 \\
\hline & Minimum & -1 & -2 & -3 \\
\hline & Rata-rata & -3 & -6 & -9 \\
\hline \multirow{3}{*}{$\geq 10$} & Maksimum & -2 & -4 & -6 \\
\hline & Minimum & -2 & -4 & -6 \\
\hline & Rata-rata & -6 & -12 & -18 \\
\hline
\end{tabular}

Sumber: Kepmen LH Nomor 115 Tahun 2003.

Tabel 4. Sistem Nilai Penentuan Status Mutu Air

\begin{tabular}{ccccl}
\hline No & \multicolumn{2}{c}{ Kategori } & Skor & Status \\
\hline 1 & Kelas A & Baik sekali & 0 & Memenuhi Baku Mutu \\
2 & Kelas B & Baik & $-1 \mathrm{~s} / \mathrm{d}-10$ & Cemar Ringan \\
3 & Kelas C & Sedang & $-11 \mathrm{~s} / \mathrm{d}-30$ & Cemar Sedang \\
4 & Kelas D & Buruk & $>-31$ & Cemar Berat \\
\hline
\end{tabular}

Sumber: Kepmen LH Nomor 115 Tahun 2003.

\section{HASIL}

\section{Kondisi Kualitas Air Sungai}

Analisis kualitas air dilakukan untuk mengetahui kesesuaian air untuk peruntukan tertentu dengan membandingkan dengan baku mutu air sesuai kelas air. Berdasarkan peruntukannya, Sungai Parit 11 dan Sungai Parit 13 merupakan golongan air kelas III, maka hasil pemantauan parameter fisika (suhu dan TSS) dan kimia ( $\mathrm{pH}, \mathrm{DO}, \mathrm{COD}, \mathrm{BOD}$, Phosfat dan nitrat) pada masing-masing stasiun pengamatan dalam penelitian ini, selanjutnya dibandingkan dengan baku mutu air kelas III berdasarkan PP Nomor 82 Tahun 2001. Hasil analisa terhadap masing-masing parameter kualitas air sungai secara rinci disajikan pada Tabel 5.

Tabel 5. Kualitas air sungai yang mengalir di Kecamatan Tembilahan Hulu Kabupaten Indragiri Hilir

\begin{tabular}{|c|c|c|c|c|c|c|c|c|}
\hline Stasiun & $\begin{array}{l}\text { Suhu } \\
\left({ }^{0} \mathrm{C}\right)\end{array}$ & $\begin{array}{c}\text { TSS } \\
(\mathrm{mg} / \mathrm{l})\end{array}$ & $\mathrm{pH}$ & $\begin{array}{c}\mathrm{DO} \\
(\mathrm{mg} / \mathrm{l})\end{array}$ & $\begin{array}{l}\text { COD } \\
(\mathrm{mg} / \mathrm{l})\end{array}$ & $\begin{array}{l}\text { BOD } \\
(\mathrm{mg} / \mathrm{l})\end{array}$ & $\begin{array}{l}\text { Posfat } \\
(\mathrm{mg} / \mathrm{l})\end{array}$ & $\begin{array}{l}\text { Nitrat } \\
(\mathrm{mg} / \mathrm{l})\end{array}$ \\
\hline \multicolumn{9}{|c|}{ Kondisi Pasang } \\
\hline 1 & 29,98 & 182,00 & 6,78 & 2,50 & 35,39 & 0,30 & 0,26 & 0,63 \\
\hline 2 & 30,34 & 194,00 & 6,79 & 1,25 & 30,34 & 0,66 & 0,36 & 0,65 \\
\hline 3 & 30,09 & 230,00 & 6,92 & 1,23 & 65,73 & 0,81 & 0,37 & 0,67 \\
\hline 4 & 29,48 & 344,00 & 6,97 & 1,69 & 35,39 & 0,86 & 0,16 & 0,61 \\
\hline 5 & 30,35 & 358,00 & 7,10 & 1,20 & 48,03 & 0,89 & 0,22 & 0,62 \\
\hline 6 & 30,50 & 438,00 & 6,73 & 1,12 & 37,92 & 0,92 & 0,29 & 0,62 \\
\hline \multicolumn{9}{|c|}{ Kondisi Surut } \\
\hline 1 & 28,64 & 64,00 & 7,08 & 3,14 & 28,80 & 18,72 & 1,16 & 0,09 \\
\hline 2 & 30,73 & 92,00 & 7,07 & 1,98 & 16,80 & 10,92 & 1,30 & 0,10 \\
\hline 3 & 30,78 & 731,00 & 6,69 & 1,58 & 36,00 & 23,04 & 1,36 & 0,11 \\
\hline 4 & 31,50 & 36,00 & 7,68 & 4,52 & 62,40 & 40,56 & 0,24 & 0,11 \\
\hline 5 & 31,97 & 264,00 & 7,39 & 2,04 & 64,80 & 42,12 & 1,12 & 0,12 \\
\hline 6 & 32,19 & 696,00 & 6,97 & 1,35 & 57,60 & 37,44 & 2,28 & 0,12 \\
\hline
\end{tabular}




\section{Status Mutu Air Sungai}

Status mutu air adalah tingkat kondisi mutu air yang menunjukan kondisi cemar atau kondisi baik pada suatu sumber air dalam waktu tertentu dengan membandingkan dengan baku mutu air yang ditetapkan. Parameter yang digunakan dalam penelitian yaitu TSS, $\mathrm{pH}, \mathrm{DO}$, COD, BOD, Phosfat dan nitrat. Baku mutu air yang digunakan yaitu baku mutu air kelas III berdasarkan PP No. 82 Tahun (Tabel 6). Parameter yang masih berada pada ambang batas yang ditetapkan oleh baku mutu air kelas III berdasarkan PP No. 82 Tahun 2001 yaitu suhu, $\mathrm{pH}$ dan Nitrat. Sedangkan nilai parameter TSS, BOD, COD, DO dan Phosfat diketahui relatif sudah tidak sesuai dengan baku mutu dan peruntukannya. Selanjutnya, dilakukan analisis status mutu untuk parameter kualitas air di kedua aliran sungai dengan menggunakan metode indeks STORET. Metode ini bertujuan untuk mengetahui tingkat pencemaran perairan di wilayah pengamatan secara komprehensif. Hasil perhitungan status mutu air Sungai Parit 11 dan Sungai Parit 13 menggunakan metode STORET (Tabel 7).

Tabel 6. Parameter Kualitas Air yang Tidak Memenuhi Baku Mutu Air Kelas III (x) di Dua Aliran Sungai Kecamatan Tembilahan Hulu

\begin{tabular}{|c|c|c|c|c|c|c|c|c|c|c|}
\hline \multirow{2}{*}{ Sungai } & \multirow{2}{*}{ Kondisi } & \multirow{2}{*}{ Stasiun } & \multicolumn{8}{|c|}{ Parameter } \\
\hline & & & Suhu & TSS & $\mathrm{pH}$ & BOD & COD & DO & Phosfat & Nitrat \\
\hline \multirow{6}{*}{ Parit 11} & \multirow{3}{*}{ Pasang } & Hulu & & $\mathrm{x}$ & & & $\mathrm{x}$ & $\mathrm{x}$ & $\mathrm{x}$ & \\
\hline & & Tengah & & $\mathrm{x}$ & & & $\mathrm{x}$ & $\mathrm{x}$ & $\mathrm{x}$ & \\
\hline & & Hilir & & $\mathrm{x}$ & & & $\mathrm{x}$ & $\mathrm{x}$ & $\mathrm{x}$ & \\
\hline & \multirow{3}{*}{ Surut } & Hulu & & $\mathrm{x}$ & & $\mathrm{x}$ & $\mathrm{x}$ & $\mathrm{x}$ & & \\
\hline & & Tengah & & $\mathrm{x}$ & & $\mathrm{x}$ & & $\mathrm{x}$ & & \\
\hline & & Hilir & & $\mathrm{x}$ & & $\mathrm{x}$ & $\mathrm{x}$ & $\mathrm{x}$ & & \\
\hline \multirow{6}{*}{ Parit 13} & \multirow{3}{*}{ Pasang } & Hulu & & $\mathrm{x}$ & & & $\mathrm{X}$ & $\mathrm{x}$ & & \\
\hline & & Tengah & & $\mathrm{x}$ & & & $\mathrm{x}$ & $\mathrm{x}$ & $\mathrm{x}$ & \\
\hline & & Hilir & & $\mathrm{x}$ & & & $\mathrm{x}$ & $\mathrm{x}$ & $\mathrm{x}$ & \\
\hline & \multirow{3}{*}{ Surut } & Hulu & & $\mathrm{x}$ & & $\mathrm{x}$ & $\mathrm{x}$ & & $\mathrm{x}$ & \\
\hline & & Tengah & & $\mathrm{x}$ & & $\mathrm{x}$ & $\mathrm{x}$ & $\mathrm{x}$ & & \\
\hline & & Hilir & & $\mathrm{x}$ & & $\mathrm{x}$ & $\mathrm{x}$ & $\mathrm{x}$ & $\mathrm{x}$ & \\
\hline
\end{tabular}

Tabel 7. Status Mutu Kualitas Air Menurut Sistem Nilai STORET di Dua Aliran Sungai Kecamatan Tembilahan Hulu Bagi Peruntukan Air Kelas III (PP 82/2001)

\begin{tabular}{|c|c|c|c|c|c|c|c|c|}
\hline \multirow[b]{2}{*}{ Parameter } & \multirow[b]{2}{*}{ Satuan } & \multirow{2}{*}{$\begin{array}{c}\text { Baku } \\
\text { Mutu* }\end{array}$} & \multirow[b]{2}{*}{ Sungai } & \multicolumn{3}{|c|}{ Hasil Pengukuran } & \multirow[b]{2}{*}{ Skor** } & \multirow[b]{2}{*}{$\begin{array}{c}\text { Rata- } \\
\text { rata }\end{array}$} \\
\hline & & & & Maks & Min & $\begin{array}{c}\text { Rata- } \\
\text { rata }\end{array}$ & & \\
\hline \multirow[t]{2}{*}{ TSS } & \multirow[t]{2}{*}{$\mathrm{mg} / \mathrm{l}$} & \multirow[t]{2}{*}{50} & Parit 11 & 480,5 & 123 & 248,83 & -10 & \multirow[b]{2}{*}{10} \\
\hline & & & Parit 13 & 567 & 190 & 356 & -10 & \\
\hline \multirow[t]{2}{*}{$\mathrm{pH}$} & \multirow[t]{2}{*}{$\mathrm{mg} / \mathrm{l}$} & \multirow[t]{2}{*}{$6-9$} & Parit 11 & 6,93 & 6,81 & 6,89 & 0 & \multirow{2}{*}{0} \\
\hline & & & Parit 13 & 7,33 & 6,86 & 7,14 & 0 & \\
\hline \multirow[t]{2}{*}{ BOD } & \multirow[t]{2}{*}{$\mathrm{mg} / \mathrm{l}$} & \multirow[t]{2}{*}{3} & Parit 11 & 11,93 & 5,79 & 9,08 & -20 & \multirow{2}{*}{20} \\
\hline & & & Parit 13 & 21,15 & 19,18 & 20,47 & -20 & \\
\hline \multirow{2}{*}{ COD } & \multirow{2}{*}{$\mathrm{mg} / \mathrm{l}$} & \multirow{2}{*}{25} & Parit 11 & 50,87 & 23,57 & 35,51 & -20 & \multirow{2}{*}{20} \\
\hline & & & Parit 13 & 56,42 & 47,76 & 51,02 & -20 & \\
\hline \multirow[t]{2}{*}{ DO } & \multirow[t]{2}{*}{$\mathrm{mg} / \mathrm{l}$} & \multirow[t]{2}{*}{4} & Parit 11 & 2,82 & 1,41 & 1,95 & -16 & \multirow{2}{*}{14,66} \\
\hline & & & Parit 13 & 3,11 & 1,24 & 1,99 & -20 & \\
\hline \multirow[t]{2}{*}{ Phosfat } & \multirow[t]{2}{*}{$\mathrm{mg} / \mathrm{l}$} & \multirow[t]{2}{*}{0,2} & Parit 11 & 0,86 & 0,71 & 0,8 & -20 & \multirow[t]{2}{*}{18,66} \\
\hline & & & Parit 13 & 0,67 & 0,37 & 0,72 & -20 & \\
\hline \multirow[t]{2}{*}{ Nitrat } & \multirow[t]{2}{*}{$\mathrm{mg} / \mathrm{l}$} & \multirow[t]{2}{*}{10} & Parit 11 & 0,39 & 0,36 & 0,37 & 0 & \multirow{2}{*}{0} \\
\hline & & & Parit 13 & 0,36 & 0,37 & 0,37 & 0 & \\
\hline
\end{tabular}

Keterangan: ${ }^{*}=$ Baku Mutu PP No. 82 Tahun 2001; ** = KLH No. 115 Tahun 2001. 


\section{PEMBAHASAN}

\section{Identifikasi Sumber Pencemaran Sungai}

Hasil identifikasi terhadap Sungai Parit 11 dan Sungai Parit 13 diketahui bahwa sumber pencemaran perairan di kedua sungai ini terbagi atas dua yaitu sumber pencemar yang bersifat terpusat (point source) dan sumber pencemar yang bersifat tersebar (non-point/diffuse source). Sumber pencemar point source bersumber dari kegiatan pertanian dan industri skala kecil yang terdapat di sekitar bantaran sungai. Sedangkan sumber pencemar nonpoint source berasal dari limpasan areal pertanian yang mengandung pestisida dan pupuk di bagian hulu sungai, limpasan limbah dari permukiman (domestik) dan limpasan dari daerah perkotaan.

Berdasarkan aktivitas disekitar bantaran sungai, masukan limbah di Sungai Parit 11 pada bagian tengah hingga ke hilir didominasi oleh limbah aktivitas Puskesmas, rumah bersalin, hotel/penginapan, permukiman dan kegiatan pengepulan barang bekas yang berasal dari luar negeri. Demikian pula masukan limbah pada bagian tengah hingga hilir di Sungai Parit 13 yang di dominasi oleh aktivitas perbengkelan, rumah makan, hotel/penginapan, permukiman dan beberapa klinik kesehatan. Sedangkan masukan limbah pada bagian hulu dari kedua sungai ini di dominasi oleh kegiatan pertanian dan perladangan padi.

Sumber pencemar dari beberapa kegiatan antropogenik di kedua sungai secara umum menghasilkan limbah organik dan anorganik. Limbah organik merupakan limbah yang tergolong dapat terdegradasi/terurai secara sendiri atau self purification (apabila debit limbah organik < debit sungai). Sedangkan apabila limbah cair yang dihasilkan banyak namun debit sungai kecil maka limbah cair organik tidak akan dapat terdegradasi/terurai dengan sendirinya dan akan diakumulasi oleh biota perairan. Adanya keterkaitan antara konsentrasi limbah di badan sungai dengan debit air mengindikasikan bahwa kondisi pasang dan surut sungai akan berpengaruh signifikan terhadap konsentrasi bahan pencemar di Sungai Parit 11 dan Sungai Parit 13.

\section{Analisa Kualitas Air Sungai}

\section{1) Suhu}

Berdasarkan hasil pemantauan parameter suhu air Sungai pada masing-masing stasiun pengamatan menunjukan bahwa tidak terjadi perbedaan yang besar atau relatif stabil yang berkisar antara $29,48-32,27{ }^{0} \mathrm{C}$ pada saat pasang dan $28,64-32,19{ }^{\circ} \mathrm{C}$ pada saat kondisi surut. Suhu terendah pada saat kondisi pasang berada pada bagian hulu Sungai Parit 13 dan suhu tertinggi berada pada bagian hilir Sungai Parit 13. Sedangkan suhu terendah pada kondisi surut berada pada bagian hulu Sungai Parit 11 dan suhu tertinggi tetap berada pada bagian hilir Sungai Parit 13. Jika dibandingkan dengan baku mutu air kelas III berdasarkan PP Nomor 82 Tahun 2001 yaitu deviasi 3 dari keadaan alamiah, maka kondisi kualitas air Sungai Parit 11 dan Sungai Parit 13 ditinjau dari parameter suhu masih dalam batas baku mutu air sesuai peruntukannya.

Suhu suatu perairan dapat mempengaruhi kelulushidupan organisme yang berada di dalamnya termasuk plankton. Menurut Barus (2001) hal itu terjadi karena suhu suatu perairan akan mempengaruhi kelarutan oksigen yang sangat diperlukan organisme akuatik untuk metabolismenya. Semakin tinggi suhu suatu perairan, kelarutan oksigennya semakin menurun. Peningkatan suhu juga menyebabkan terjadinya peningkatan dekomposisi bahan organik oleh mikroba. Kisaran suhu optimum bagi pertumbuhan fitoplankton di perairan adalah $20{ }^{0} \mathrm{C}-30{ }^{\circ} \mathrm{C}$ (Effendi, 2003). Sehingga suhu air di Sungai Parit 11 dan Sungai Parit 13 dapat dikatakan masih mendukung dalam hal pertumbuhan fitoplankton.

\section{2) TSS (Total Suspended Solid)}

Berdasarkan hasil pemantauan parameter TSS pada setiap stasiun pengamatan menunjukan terjadinya peningkatan dari hulu ke hilir sungai. Kisaran nilai TSS yang diperoleh selama pengamatan yaitu $182-438 \mathrm{mg} / \mathrm{l}$ pada saat pasang dan $64-696 \mathrm{mg} / \mathrm{l}$ pada kondisi surut. Merujuk pada baku mutu air kelas III berdasarkan PP Nomor 82 Tahun 2001 yaitu 50 mg/l, maka kondisi kualitas air Sungai Parit 11 dan Sungai Parit 13 ditinjau dari parameter TSS telah jauh melampaui ambang batas maksimum 
baku mutu air dan sudah tidak sesuai peruntukannya.

Relatif tingginya nilai TSS sangat terkait dengan karakteristik sungai rawa yang dipengaruhi pasang surut yang menyebabkan terjadinya proses pengadukan sedimen dasar perairan. TSS terdiri dari lumpur dan pasir halus serta jasad-jasad renik, yang disebabkan oleh kikisan tanah atau erosi tanah yang terbawa ke badan air (Effendi, 2003). Adanya peningkatan nilai TSS air Sungai Parit 11 dan Sungai Parit 13 terutama pada bagian tengah hingga hilir perairan, dikarenakan tingginya alih fungsi lahan menjadi daerah terbangun/ permukiman di sekitar DAS, sehingga menyebabkan padatanpadatan tanah yang memasuki aliran sungai melalui run off semakin meningkat. Tingginya nilai TSS di kedua Sungai akan berpengaruh secara signifikan terhadap kepentingan perikanan yang mensyaratkan nilai TSS antara 25 - $80 \mathrm{mg} / \mathrm{l}$ (Effendi, 2003).

\section{3) $\mathrm{pH}$}

Hasil pemantauan parameter $\mathrm{pH}$ pada setiap stasiun pengamatan berkisar antara 6,737,10 saat kondisi pasang dan $6,69-7,68$ saat kondisi surut. Nilai $\mathrm{pH}$ terendah pada saat kondisi pasang berada pada bagian hilir Sungai Parit 13 dan nilai $\mathrm{pH}$ tertinggi berada pada bagian tengah Sungai Parit 13. Pada kondisi surut nilai $\mathrm{pH}$ terendah terdapat pada bagian hilir Sungai Parit 11 dan nilai $\mathrm{pH}$ tertinggi berada pada bagian hulu Parit 13. Apabila dibandingkan dengan baku mutu air kelas III berdasarkan PP Nomor 82 Tahun 2001 yaitu berkisar antara 6 - 9, maka kondisi kualitas air Sungai Parit 11 dan Sungai Parit 13 ditinjau dari parameter $\mathrm{pH}$ masih dalam batas baku mutu air sesuai peruntukannya.

Terjadinya perbedaan nilai $\mathrm{pH}$ pada masing-masing stasiun pengamatan diduga akibat adanya masukan limbah organik dan anorganik dari kegiatan antropogenik yang ada di sepanjang bantaran sungai. Hal ini sesuai dengan pendapat Yuliastuti (2011) yang menyatakan bahwa fluktuasi nilai $\mathrm{pH}$ dipengaruhi oleh adanya buangan limbah organik dan anorganik ke sungai. Peningkatan nilai $\mathrm{pH}$ air di kedua Sungai pada saat kondisi surut menjadi indikasi bahwa adanya aktivitas pembuangan limbah organik yang bersumber dari limbah domestik pada daerah tengah dan hilifr sungai maupun limbah yang berasal dari aktivitas pertanian di bagian hulu sungai yang masuk ke badan Sungai. Air normal yang memenuhi syarat untuk suatu kehidupan mempunyai $\mathrm{pH}$ sekitar 6,5 - 7,5 (Wardhana, 2004). Nilai $\mathrm{pH}$ air yang tidak tercemar biasanya mendekati netral $(\mathrm{pH}$ 7) dan memenuhi kehidupan hampir semua organisme air (Syofyan et al., 2011). Sehingga nilai pH air pada bagian hulu dan tengah Sungai Parit 11 dan Sungai Parit 13 pada kondisi surut telah melampaui syarat nilai parameter $\mathrm{pH}$ untuk kehidupan organisme air.

\section{4) DO}

Parameter oksigen terlarut dapat digunakan sebagai indikator tingkat kesegaran air (Sutriati, 2011). Oksigen memegang peranan penting sebagai indikator kualitas perairan, karena oksigen terlarut berperan dalam proses oksidasi dan reduksi bahan organik dan anorganik. Karena proses oksidasi dan reduksi inilah maka peranan oksigen terlarut sangat penting untuk membantu mengurangi beban pencemaran pada perairan secara alami (Salmin, 2005). Hasil pemantauan parameter DO pada setiap stasiun pengamatan berkisar antara 1,12 $2,50 \mathrm{mg} / \mathrm{l}$ saat kondisi sungai pasang dan 1,35 $4,52 \mathrm{mg} / \mathrm{l}$ saat kondisi surut. Nilai DO terendah pada saat kondisi pasang berada pada bagian hilir Sungai Parit 13 dan nilai DO tertinggi berada pada bagian hulu Sungai Parit 11 . Demikian pula halnya pada saat kondisi surut, diketahui nilai DO terendah berada di bagian hilir Sungai Parit 13 dan nilai DO tertinggi terdapat pada Hulu Sungai Parit 13.

Hasil pengamatan terhadap konsentrasi DO pada masing-masing stasiun pengamatan menunjukkan konsentrasi DO yang relatif rendah. Menurut Barus (2001) nilai DO diperairan sebaiknya berkisar antara $6-8 \mathrm{mg} / \mathrm{l}$. Terlihat kecenderungan penurunan konsentrasi DO dari bagian hulu ke bagian tengah dan hilir sungai. Hal ini diprediksi akibat semakin tingginya masukan limbah seiring dengan semakin padatnya aktivitas antropogenik pada bagian tengah dan hilir sungai. Pada umumnya air yang telah tercemar kandungan oksigennya sangat rendah, makin banyak bahan buangan organik di dalam air makin sedikit sisa kandungan oksigen yang terlarut di dalam air (Wardhana, 2004). Aktivitas manusia seperti 
pertanian dan pembuangan limbah, menyebabkan penurunan konsentrasi oksigen terlarut (Blume et al., 2010).

Jika dibandingkan dengan baku mutu air kelas III untuk parameter DO berdasarkan PP Nomor 82 Tahun 2001 yaitu sebesar 4 mg/l, maka kondisi kualitas air sungai ditinjau dari parameter DO di hampir seluruh stasiun pengamatan telah berada dibawah baku mutu dan tidak sesuai dengan peruntukannya. Terkecuali pada Stasiun 4 yang merupakan bagian hulu Sungai Parit 13 yang memiliki nila DO sebesar 4,52 mg/l pada kondisi air surut. Hal ini menandakan bahwa kualitas air Sungai Parit 11 dan Sungai Parit 13 berdasarkan parameter DO, memiliki tingkat pencemaran yang tinggi.

\section{5) Chemical Oxygen Demand (COD)}

COD adalah banyaknya oksigen yang dibutuhkan untuk mengoksidasi bahan-bahan organik secara kimia (Yudo, 2010). Hasil pemantauan parameter COD pada setiap stasiun pengamatan berkisar antara 30,34 - 65,73 mg/l saat kondisi sungai pasang dan 16,80 - 64,80 $\mathrm{mg} / \mathrm{l}$ saat kondisi surut. Nilai COD terendah pada saat kondisi pasang berada pada bagian tengah Sungai Parit 11 dan nilai COD tertinggi berada pada bagian hilir Sungai Parit 11. Pada saat kondisi surut nilai COD tertinggi berada di bagian tengah Sungai Parit 13 dan nilai COD terendah terdapat di bagian tengah Sungai Parit 11. Merujuk pada ketentuan PP Nomor 82 Tahun 2001 tentang baku mutu air kelas III, kisaran konsentrasi COD saat kondisi pasang maupun surut telah melewati nilai ambang batas baku mutu yang ditetapkan yaitu sebesar 25 $\mathrm{mg} / \mathrm{l}$ terkecuali pada bagian tengah Sungai Parit 11 pada saat kondisi surut.

Hasil pemantauan konsentrasi COD memperlihatkan kecenderungan peningkatan konsentrasi COD dari bagian hulu ke hilir sungai baik pada saat kondisi pasang maupun surut. Hal ini disebabkan oleh masukan beban pencemaran yang berasal dari limbah domestik, rumah makan, pasar, penginapan dan industri skala kecil dan klinik pelayanan kesehatan. Terintroduksinya beban pencemaran dari limbah domestik, rumah makan dan penginapan melalui saluran air maupun saluran drainase di sepanjang aliran Sungai juga mempengaruhi besarnya fluktuasi nilai COD. Faktor pengukuran pada waktu pasang dan pada waktu surut juga mempengaruhi fluktuasi nilai COD di kedua sungai. Hal ini selaras dengan pendapat Ali et al., (2013) yang menyatakan bahwa keberadaan COD di Sungai biasanya bersumber dari limbah domestik, limbah industri, limbah ternak dan limbah agroindustri.

$$
\text { Angka COD yang tinggi, }
$$

mengindikasikan semakin besar tingkat pencemaran yang terjadi (Yudo, 2010). Perairan yang memiliki nilai COD tinggi tidak diinginkan bagi kepentingan perikanan dan pertanian. Nilai COD pada perairan yang tidak tercemar biasanya kurang dari $20 \mathrm{mg} / \mathrm{l}$, sedangkan pada perairan tercemar dapat lebih dari $200 \mathrm{mg} / \mathrm{l}$ (Effendi, 2003). Dengan demikian maka kualitas air Sungai Parit 11 dan Sungai Parit 13 untuk parameter COD, sudah tidak dapat mendukung kepentingan perikanan dan pertanian karena dalam kondisi tercemar.

\section{6) Biochemical Oxygen Demand (BOD)}

BOD adalah jumlah oksigen terlarut yang dibutuhkan oleh bakteri pengurai untuk menguraikan bahan pencemar organik dalam air. Makin besar kosentrasi BOD suatu perairan, menunjukan konsentrasi bahan organik di dalam air juga tinggi (Yudo, 2010). Hasil pemantauan parameter BOD air sungai saat kondisi pasang berkisar 0,30 - 0,92 mg/l dan 10,92 - 42,12 $\mathrm{mg} / \mathrm{l}$ pada saat kondisi surut. Nilai BOD terendah pada saat kondisi pasang berada pada bagian hulu Sungai Parit 11 dan nilai BOD tertinggi berada pada bagian hilir Sungai Parit 13. Pada saat kondisi surut nilai BOD terendah terdapat pada bagian tengah Sungai Parit 11 dan nilai BOD tertinggi terdapat pada bagian tengah Sungai Parit 13. Merujuk pada ketentuan PP Nomor 82 Tahun 2001 tentang baku mutu air kelas III untuk parameter BOD yaitu sebesar 3,0 $\mathrm{mg} / \mathrm{l}$, maka kondisi kualitas air sungai pada kondisi pasang masih dalam batas baku mutu air yang ditetapkan, sedangkan kondisi parameter BOD sungai pada saat kondisi surut telah jauh melampaui nilai ambang batas yang ditetapkan dan sudah tidak sesuai peruntukannya.

Tingginya nilai parameter BOD dan adanya kecenderungan peningkatan konsentrasi BOD dari hulu ke hilir sungai membuktikan bahwa masukan limbah organik dari aktivitas antropogenik di sepanjang Sungai Parit 11 dan Sungai Parit 13 relatif tinggi. Kondisi sungai surut menyebabkan bahan pencemar organik 
mengalir menuju muara sungai sehingga nilai BOD di daerah hilir akan cenderung meningkat dibandingkan daerah tengah dan hulu sungai. Sebaliknya, kondisi pasang air sungai akan menyebabkan terjadi pencampuran debet air yang berasal dari Sungai Indragiri dan terdistribusi ke seluruh sungai-sungai yang ada di Kota Tembilahan, sehingga nilai BOD relatif lebih kecil dibandingkan pada waktu surut. Tingginya nilai BOD pada bagian tengah Sungai Parit 13 diakibatkan oleh tingginya kandungan bahan organik di perairan yang diprediksi berasal dari limbah rumah tangga dan pasar. Peningkatan angka BOD di perairan pada umumnya berasal dari bahan-bahan organik dari limbah domestik dan limbah lainnya (Rahayu dan Tontowi, 2009). Pembuangan limbah dari permukiman dan lahan pertanian ke sungai biasanya akan meningkatkan nilai BOD perairan (Anhwange et al., 2012).

Semakin tinggi konsentrasi BOD di suatu perairan mengindikasikan bahwa perairan tersebut telah tercemar. Kadar BOD dalam air yang tingkat pencemarannya masih rendah dan dapat dikategorikan sebagai perairan yang baik berkisar 0 - 10 ppm (Salmin, 2005). Kualitas air Sungai Parit 11 dan Sungai Parit 13 saat kondisi surut telah jauh melampaui rentang atau batas tersebut. Semakin meningkatnya konsentrasi BOD dari hulu ke hilir mengindikasikan bahwa ke dua sungai yang mengalir di Kecamatan Tembilahan Hulu telah tercemar akibat buangan limbah domestik dan pertanian yang tersebar pada disekitar sempadan bagian tengah dan hulu sungai.

\section{7) Phosfat}

Phosfat merupakan bentuk fosfor yang dapat dimanfaatkan oleh tumbuhan. Karakteristik fosfor sangat berbeda dengan unsur-unsur utama lain yang merupakan penyusun biosfer karena unsur ini tidak terdapat di atmosfer dan sangat mudah larut dalam air serta bersifat stabil. Senyawa ini dihasilkan dari proses oksidasi sempurna senyawa nitrogen di perairan (Effendi, 2003). Konsentrasi Phosfat yang didapat selama penelitian berkisar antara $0,16-0,37 \mathrm{mg} / \mathrm{l}$ saat kondisi pasang dan 0,24 $2,28 \mathrm{mg} / \mathrm{l}$ saat kondisi surut. Konsentrasi Phosfat terendah pada saat kondisi pasang berada pada bagian hulu Sungai Parit 11 dan nilai Phosfat tertinggi berada pada bagian hilir
Sungai Parit 11. Pada saat kondisi surut nilai Phosfat terendah berada pada bagian hulu Sungai Parit 13 dan nilai Phosfat tertinggi terdapat di bagian hilir Sungai Parit 13. Merujuk pada ketentuan PP Nomor 82 Tahun 2001 tentang baku mutu air kelas III untuk parameter Phosfat yaitu sebesar $0,2 \mathrm{mg} / \mathrm{l}$, nilai kisaran Phosfat pada masing-masing stasiun pengamatan sudah jauh melampaui ambang batas baku mutu yang ditetapkan kecuali pada saat kondisi pasang dimana didapati konsentrasi Phosfat pada bagian hulu Sungai Parit 13 masih berada dibawah ambang batas baku mutu yang ditetapkan. Sedangkan menurut PHILMINAQ (2013) konsentrasi Phosfat untuk kegiatan akuakultur pada perairan tawar harus lebih kecil dari 0,10 mg/l. Berdasarkan ketentuan tersebut, maka kondisi kualitas air Sungai Parit 11 dan Sungai Parit 13 dalam kondisi tercemar dan sudah tidak mendukung kegiatan akuakultur.

Pribadi (2005) menyatakan bahwa kenaikan konsentrasi Phosfat menyatakan adanya zat pencemar akibat masukan limbah organik. Fluktuasi konsentrasi Phosfat di kedua sungai memiliki kecenderungan peningkatan konsentrasi dari hulu ke hilir terutama pada saat kondisi surut. Pada saat kondisi surut debet air Sungai Indragiri tidak terlalu mempengaruhi kondisi perairan sungai-sungai yang mengalir di Kecamatan Tembilahan Hulu. Sehingga bahan pencemar akan terkonsentrasi pada tubuh air dan bermuara ke bagian hilir sungai. Kondisi inilah yang menyebabkan nilai Phosfat bagian hilir relatif lebih tinggi dibanding bagian tengah dan hulu sungai. Pada bagian hulu sungai, konsentrasi Phosfat diprediksi berasal dari bahan pupuk dari aktivitas pertanian yang masuk ke dalam sungai melalui drainase dan aliran air hujan. Hal ini sesuai dengan Winata, et. al (2000) yang menyatakan bahwa konsentrasi $\mathrm{n}$ Phosfat di dalam perairan sungai biasanya berasal dari buangan pertanian, pupuk, kotoran hewan dan manusia. Konsentrasi Phosfat yang relatif lebih kecil dibandingkan daerah tengah dan hilir diduga akibat terjadinya proses pengenceran secara alami sepanjang aliran Sungai sehingga kosentrasi bahan pencemar mengalami penurunan.

\section{7) Nitrat}

Nitrat mewakili produk akhir dari pengoksidasian zat yang bersifat nitrogen. 
Nitrogen di perairan terdapat dalam berbagai bentuk seperti gas $\left(\mathrm{N}_{2}\right)$, nitrit $\left(\mathrm{NO}_{2}{ }^{-}\right)$, nitrat $\left(\mathrm{NO}_{3}{ }^{-}\right)$, ammonia $\left(\mathrm{NH}_{3}\right)$ dan amonium $\left(\mathrm{NH}_{4}{ }^{+}\right)$ serta sejumlah besar $\mathrm{N}$ yang berikatan dalam organik kompleks (APHA dalam Mayani, 2000). Hasil pemantauan parameter nitrat pada setiap stasiun pengamatan berkisar antara 0,61 $0,67 \mathrm{mg} / \mathrm{l}$ saat kondisi sungai pasang dan 0,09 $0,12 \mathrm{mg} / \mathrm{l}$ saat kondisi surut. Konsentrasi nitrat terendah pada saat kondisi pasang berada pada bagian hulu Sungai Parit 13 dan nilai nitrat tertinggi berada pada bagian hilir Sungai Parit 11. Pada saat kondisi surut nilai nitrat terendah berada di bagian hulu Sungai Parit 11 dan nilai nitrat tertinggi terdapat pada bagian tengah dan hilir Sungai Parit 13. Merujuk pada ketentuan PP Nomor 82 Tahun 2001 tentang baku mutu air kelas III untuk patrameter nitrat yaitu sebesar $10 \mathrm{mg} / \mathrm{l}$, konsentrasi nitrat perairan baik pada saat pasang maupun surut masih dibawah ambang batas baku mutu yang ditetapkan.

\section{Analisa Status Mutu Air Sungai}

Secara umum kondisi kualitas air di kedua sungai yang mengaliri Kecamatan
Tembilahan Hulu menunjukkan kondisi tercemar. Kondisi perairan yang tercemar disebabkan oleh keberadaan beberapa parameter kualitas fisika dan kimia air yang tidak sesuai dengan baku mutu. Hasil perhitungan status mutu air dengan metode indeks STORET tersebut diatas terlihat bahwa kualitas air Sungai Parit 11 dan Sungai Parit 13 secara umum telah mengalami pencemaran. Pencemaran yang terjadi di kedua sungai dapat dilihat dari beberapa parameter seperti konsentrasi TSS dengan status tercemar ringan. Sedangkan parameter BOD, COD, DO dan Phosfat saat ini masuk dalam kategori tercemar sedang. Hasil perhitungan nilai konsentrasi paramater kualitas air pada masing-masing stasiun pengamatan selanjutnya diklasifikasikan berdasarkan Indeks STORET dengan cara menjumlahkan semua skor yang diperoleh dari masing-masing parameter. Hasil klasifikasi status mutu perairan berdasarkan nilai skor Indeks STORET di kedua sungai yang mengalir di Kecamatan Tembilahan Hulu dapat dilihat pada Gambar 2.

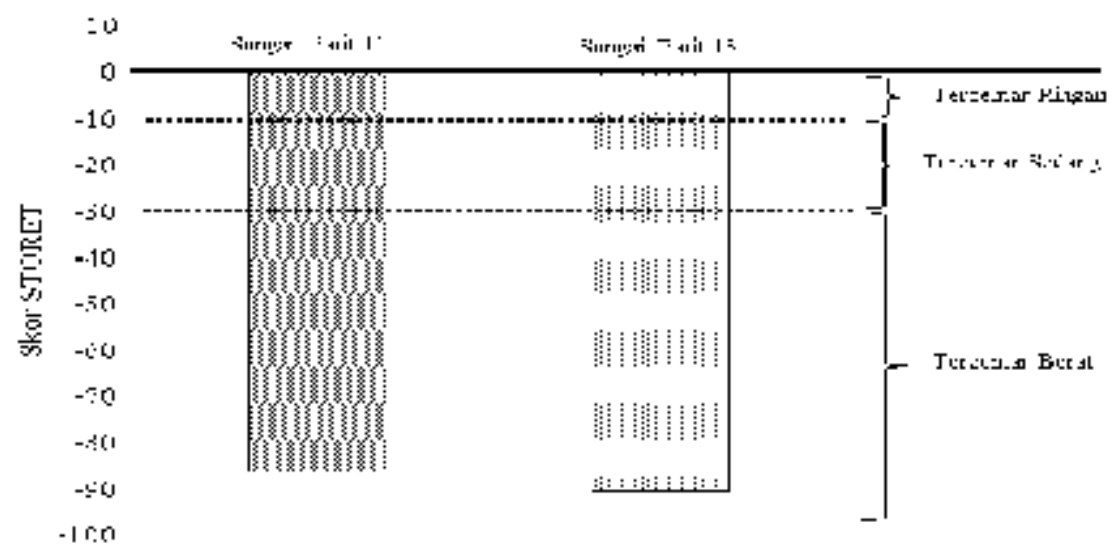

Gambar 2. Klasifikasi Status Mutu Perairan Dua Aliran Sungai di Kecamatan Tembilahan Hulu Berdasarkan Indeks STORET

Hasil klasifikasi mutu perairan Sungai Parit 11 dan Sungai Parit 13 Kecamatan Tembilahan Hulu menggunakan indeks STORET diketahui bahwa kedua sungai tersebut telah dalam kategori tercemar berat (skor $2-31$ ). Dengan demikian maka kualitas air di kedua sungai tersebut sudah tidak dapat dimanfaatkan sesuai peruntukan air kelas III yaitu untuk pembudidayaan ikan air tawar, peternakan, air untuk mengairi pertanaman, dan atau peruntukan lain yang mempersyaratkan mutu air yang sama dengan kegunaan tersebut. Sehingga diperlukan upaya pengelolaan air di kedua sungai tersebut, agar dapat tetap bermanfaat bagi kehidupan biota perairan maupun masyarakat sekitar sungai.

\section{SIMPULAN}

1. Kondisi kualitas air di kedua sungai yang mengalir di Kecamatan Tembilahan Hulu yaitu Sungai Parit 11 dan Parit 13 
berdasarkan parameter TSS, BOD, COD, DO dan Phosfat sudah tidak memenuhi ketentuan baku mutu golongan air kelas III. Sedangkan parameter Suhu, $\mathrm{pH}$ dan Nitrat masih memenuhi ketentuan baku mutu air dan masih sesuai peruntukannya.

2. Kondisi status mutu air di kedua sungai yang mengalir di Kecamatan Tembilahan Hulu menunjukkan kondisi "cemar berat" dengan nilai skor indeks STORET -86 untuk Sungai Parit 11 dan -90 untuk Sungai Parit 13 (> 31).

\section{UCAPAN TERIMA KASIH}

Ucapan terima kasih kami sampaikan Kepada Laboratorium Ekologi Perairan, Jurusan Menajemen Sumberdaya Perairan dan Laboratorium Ilmu Kelautan Fakultas Perikanan dan Ilmu Kelautan Universitas Riau, atas ijinnya dalam menggunakan alat laboratorium untuk keperluan pengambilan sampel air sungai dan melakukan pengujian sampel air sungai. Kepada ananda Arifin, S.Pi dan adinda Syaiful Ramadhan Harahap, S.Pi., M.Si, terima kasih kami ucapkan atas bantuannya dalam penelitian ini. Dan yang terakhir, kami juga mengucapkan terima kasih yang sebesar-besar kepada pengelola Jurnal Dinamika Lingkungan Indonesia, yang telah berkenan menerima dan menerbitkan artikel ini.

\section{DAFTAR PUSTAKA}

Analisis Beban dan Indeks Pencemar di Tinjau Dari Parameter Logam Berat di Sungai Siak Kota Pekanbaru.Jurnal Ilmu Lingkungan. Vol. 6(2): 162-172.

Ali, A., Soemarno dan Purnomo, M. 2013. Kajian Kualitas Air dan Status Mutu Air Sungai Metro di Kecamatan Sukun Kota Malang. Jurnal Bumi Lestari. Vol. 13(2): 265-274.

Anhwange, B.A., E.B. Agbaji, and E.C. Gimba. 2012. Impact Assessment of Human Activities and Seasonal Variation on River Benue, within Makurdi Metropolis. Journal of Science and Technology. Vol. 2: 248- 254.
Badan Lingkungan Hidup Provinsi Riau. 2015. Tabel SD-14.5. Kualitas Air Sungai Indragiri. Badan Lingkungan Hidup Provinsi Riau, Pekanbaru.

Barus, T.A., 2001. Pengantar Limnologi Suatu Studi Tentang Ekosistem. Fakultas MIPA USU. Medan.

Blume, K.K., J.C. Macedo, A. Meneguzzi, L.B. Silva, D.M. Quevedo, and M.A.S. Rodrigues. 2010. Water Quality Assessment of the Sinos River, Southern Brazil. Journal of Biology. Vol. 70: 11851193.

Effendi, H., 2003. Telaah kualitas air, bagi pengelolaan sumber daya dan lingkungan perairan. Kanisius.

Kasry, A., 2005. Air untuk Kehidupan. Presented at the Makalah dalam Rangka Peringatan Hari Air Sedunia 30-Maret2005 Provinsi Riau. Pekanbaru.

Kementerian Lingkungan Hidup. 2001. Peraturan Pemerintah Republik Indonesia Nomor 82 Tahun 2001 tentang Pengelolaan Kualitas Air dan Pendendalian Pencemaran Air.

Kementerian Lingkungan Hidup. 2003. Keputusan Menteri Lingkungan Hidup Nomor 115 Tahun 2003 tentang Pedoman Penentuan Status Mutu Air.

Mayani, I. 2000. Kesuburan Perairan Berdasarkan Kandungan Unsur Hara dan P serta Struktur Komunitas Fitoplankton di Situ Citayam, Bojong Gede, Bogor, Jawa Barat. Program Manajemen Sumberdaya Perairan. Fakultas Perikanan dan Ilmu Kelautan. Institut Pertanian Bogor. Bogor.

PHILMINAQ (2013). Annex 2 Water Quality Criteria and Standards for Freshwater and Marine Aquaculture. Mitigating Impact from Aquaculture in the Philippines.

Pribadi, M.A. 2005. Evaluasi Kualitas Air Sungai Way Sulan Kecil Kabupaten Lampung Selatan. Departemen Konservasi Sumberdaya Hutan dan Ekowisata Fakultas Kehutanan Institut Pertanian Bogor. 
Rudiyanti, S., 2011. Kualitas Perairan Sungai Banger Pekalongan Berdasarkan Indikator Biologis. J. Saintek Perikanan. Vol. 4(2): 46-52.

Salmin. 2005. Oksigen Terlarut (DO) dan Kebutuhan Oksigen Biologi (BOD) sebagai Salah Satu Indikator Untuk Menentukan Kualitas Perairan. Jurnal Oseana. Vol. 30: 21-26.

Syofyan, I., Usman, dan P. Nasution. 2011. Studi Kualitas Air Untuk Kesehatan Ikan Dalam Budidaya Perikanan Pada Aliran Sungai Kampar Kiri”. Jurnal Perikanan dan Kelautan. Vol. 16: 64-70.
Wardhana, W.A. 2004. Dampak Pencemaran Lingkungan. Penerbit Andi. Yogyakarta.

Winata, I.N.A., Siswoyo, A dan Mulyono, T. 2000. Perbandingan Kandungan $P$ dan $N$ Total Dalam Air Sungai di Lingkungan Perkebunan dan Persawahan. Jurnal Ilmu Dasar. Vol. 1: 24-28.

Yudo, S. 2010. Kondisi Kualitas Air Sungai Ciliwung di Wilayah DKI Jakarta ditinjau dari Parameter Organik, Amoniak, Fosfat, Deterjen dan Bakteri Coli. Jurnal Akuakultur Indonesia. Vol. 6: 34-42.

Yuliastuti, E. 2011. Kajian Kualitas Air Sungai Ngringo Karanganyar dalam Upaya Pengendalian Pencemaran Air. Tesis. Program Pascasarjana Universitas Diponegoro, Semarang. 